\title{
Impact of New Natural Biostimulants on Increasing Synthesis in Plant Cells of Small Regulatory si/miRNA With High Anti-Nematodic Activity
}

\author{
Victoria Anatolyivna Tsygankova ${ }^{1}$, Galyna Alexandrovna Iutynska ${ }^{2}$, Anatoliy Pavlovych Galkin ${ }^{3} \&$ Yaroslav \\ Borisovych Blume ${ }^{3}$ \\ ${ }^{1}$ Department Cell Signal System, Institute of Bioorganic Chemistry and Petrochemistry, National Academy of \\ Sciences of Ukraine, Ukraine \\ ${ }^{2}$ Department of General and Soil Microbiology, Zabolotny Institute of Microbiology and Virology, National \\ Academy of Sciences of Ukraine, Ukraine \\ ${ }^{3}$ Department Genomics and Molecular Biotechnology, Institute of Food Biotechnology and Genomics, National \\ Academy of Sciences of Ukraine, Ukraine
}

Correspondence: Victoria Anatolyivna Tsygankova, Department Cell Signal System, Institute of Bioorganic Chemistry and Petrochemistry, National Academy of Sciences of Ukraine, Kyiv, 02094, Murmanska str., 1, Ukraine. E-mail: vTsygankova@ukr.net

\author{
Received: September 12, 2013 Accepted: November 8, 2013 Online Published: November 22, 2013 \\ doi:10.5539/ijb.v6n1p48 \\ URL: http://dx.doi.org/10.5539/ijb.v6n1p48
}

\begin{abstract}
Plant endoparasitic cyst nematode Heterodera schachtii Schmidt, gallic nematode Meloidogyne incognita and stem nematode Ditylenchus destructor damage various agricultural crops. The application of ecologically safe natural biostimulants with bioprotective properties is a newer approach for increasing plant resistance to parasitic nematodes. The molecular-genetic analysis of biostimulants action on plant genome is necessary for creation of new effective bioregulators for plant protection against phytopathogenic organisms. In our field and greenhouse experiments, we investigated the influence of new natural biostimulants Avercom and its derivatives on plant protection against nematodes Meloidogyne incognita and Ditylenchus destructor. Considerable increase of resistance to nematodes and productivity of cucumber and potato were observed for plants treated by biostimulant Avercom and its derivatives. Impact of biostimulants Radostim-super and Avercom on increase of resistance of sugar beet and cucumber sprouts to nematodes Heterodera schachtii and Meloidogyne incognita was studied in the laboratory conditions. Comparative analysis of morpho-physiological signs of control and experimental plants showed that plants treated by Radostim-super and Avercom were more viable and resistant to these nematodes as compared to control sprouts. In the molecular-genetic experiments, we studied the impact of these biostimulants on inducing synthesis of small regulatory si/miRNA, which plays key role in plant immune protection. Using method Dot-blot hybridization we studied degree of homology between si/miRNA with mRNA populations, isolated from plants untreated and treated with new natural biostimulants. We found considerable difference in the degree of homology (6-28\%) between populations of mRNA and si/miRNA from nematode-infected plants that were either untreated or treated with biostimulants. We have also investigated silencing of translation of mRNA activity of si/miRNA in the wheat embryo cell-free system of protein synthesis. In these experiments, we found high inhibitory activity $(38-65 \%)$ of si/miRNA from plants treated by biostimulants as compared to low inhibitory activity (15-20\%) of si/miRNA from untreated plants. Obtained differences in the degree of homology between populations of mRNA and si/miRNA from untreated and treated with biostimulants plants, which were infected by nematode, and also the high inhibitory activity of si/miRNA from plants treated by biostimulants confirm that these biostimulants induce synthesis of anti-nematodic si/miRNA in plants, resulting in considerable increase of their resistance to these phytopathogens.
\end{abstract}

Keywords: Heterodera schachtii, Meloidogyne incognita, Ditylenchus destructor, natural biostimulants, anti-nematodic si/miRNA, the degree of homology between mRNA and si/miRNA, silencing activity of si/miRNA in the wheat embryo cell-free system of protein synthesis, plant resistance to nematodes 


\section{Introduction}

Over the last ten years a key role of short interfering RNA (siRNA) and microRNA (miRNA) in the TGS and PTGS - the basic processes of plant development and adaptation to stress-factors of environment, is disclosed (Angaji et al., 2010; Chen, 2009; Filipowicz et al., 2005; Hamilton et al., 2002; Luna et al., 2012; Mirouze et al., 2011; Park et al., 2002; Rasmann et al., 2012; Vaucheret et al., 2001; Zhang et al., 2007). The miRNA is generated from pre-miRNA precursor of $\sim 70$ nucleotides (nt) derived from one strand of distinct genomic loci by two rounds of endoribonuclease cleavage by RNase III-like enzymes named Drosha and Dicer (Lee et al., 2003; Mourelatos et al., 2002). The siRNA of 22-24-nt is generated from longer double-stranded RNA (dsRNA) molecules (derived from repetitive sequences such as transposons and transgenes) through their cleavage by RNase III endoribonuclease named Dicer (Hamilton et al., 2002).

In a process of PTGS also called RNA interference (RNAi) si/miRNA with antisense structure to mRNA functions in a dual role: 1) together with site-specific multi-subunit RNase, referred to as RNA-induced silencing complex (RISC), and with AGO (Argonaute) proteins si/miRNA determines an age period of endogenous mRNA molecule in each eukaryotic cell and 2) together with RISC and AGO proteins si/miRNA participates in enzymatic cleavage or in silencing of translation of homologous mRNA of pathogenic organisms providing protection against pathogens and parasites (Bakhetia et al., 2005; Chen, 2009; Fabian et al., 2010; Filipowicz et al., 2005; Hamilton et al., 2002; Park et al., 2002; Vaucheret et al., 2006; Zhang et al., 2007) Taking part in DNA methylation and histone modification during TGS, and silencing of translation of mRNA of various pathogenic organisms during PTGS, si/miRNA contributes to epigenetic inheritance of plant resistance to diseases (Calarco et al., 2012; Luna et al., 2012; Mirouze et al., 2011; Rasmann et al., 2012; Tsygankova, 2012).

Numerous studies have shown that during infection of plants by pathogenic organisms the changes in small RNA populations (the main components of plant immune system) occur (Hewezi et al., 2008; Katiyar-Agarwal et al., 2006; Padmanabhan et al., 2009; Patel et al., 2010). Targets for si/miRNA are mRNA transcripts of plant genes which expression is induced during infection (therefore damage of plants by phytopathogens raises), or highly homologous mRNA of pathogenic organisms (Baum et al., 2007; Hewezi et al., 2008; Katiyar-Agarwal et al., 2006; Li et al., 2012; Padmanabhan et al., 2009; Patel et al., 2010).

In the case of plant protection against pathogens and parasites, the number of si/miRNA molecules produced in plant cells in response to a mass infection is not sufficient to provide effective protection. There are two approaches to increase synthesis of si/miRNA in response to pathogen or parasite attacks; these are either to insert additional genes of si/miRNA in the cells using genetic transformation or to activate the synthesis of endogenous si/miRNA in plant cells by specific inductors, for example by phytohormones (Bakhetia et al., 2005; Gheysen et al., 2006; Padmanabhan et al., 2009; Spoel et al., 2012; Zhang et al., 2011).

In our previous investigations we have elaborated and proposed the new strategy of nematode disease management: increase of plant resistance to nematodes by the way of inducing of RNA-interference process (RNAi or PTGS) in plant cells, i.e. inducing synthesis of si/miRNA using new ecologically safe polycomponent biostimulants with bioprotective and immune-modulating effects. In our laboratory and field experiments we found that biostimulants significantly increased plant resistance to viral pathogens, nematodes and insect herbivores through stimulation of synthesis in plant cells of immune-protective small regulatory si/miRNA (Tsygankova, Andrusevich et al., 2011; Tsygankova, Galkin et al., 2011; Tsygankova, Andrusevich, Beljavskaja et al., 2012). In these works we used Dot-blot hybridization for the study of changes in the degree of homology between populations of cytoplasmic RNA and small regulatory si/miRNA, isolated from rape, sugar beet, wheat and cucumber plants of the first generation, infected by parasitic nematodes Heterodera schachtii and Meloidogyne incognita, as well as wheat and nut plants of the second generation, infected by pathogenic micromycetes Fusarium graminearum and Fusarium oxysporum $f$. ciceris (Tsygankova, 2012; Tsygankova, Andrusevich et al., 2012; Tsygankova, Ponomarenko et al., 2012; Tsygankova, Stefanovska, Andrusevich et al., 2012; Tsygankova, Stefanovska, Galkin et al., 2012; Tsygankova, Andrusevich, Beljavskaja et al., 2012). Obtained differences in the degree of homology between mRNA and si/miRNA populations we used as genetic markers of increase of plant resistance to phytopathogens. Silencing of translation of mRNA activity of si/miRNA was also verified in the experiments with wheat embryo cell-free system of protein synthesis, which is widely used along with other cell-free systems (the rabbit reticulocyte lysate system and cell-free system from syncytial blastoderm Drosophila embryos) for in vitro study of mRNA translation and for investigation of silencing activity of si/miRNA on in vitro inhibition of mRNA translation (Maniatis et al., 1982; Promega, 1991; Tang et al., 2003; Tuschl et al., 1999).

To induce the synthesis of endogenous si/miRNA we treated plant seeds by new natural polycomponent 
biostimulants with bioprotective effect - Avercom and its derivatives, created at Zabolotny Institute of Microbiology and Virology, NAS of Ukraine and biostimulants Biogene, Stimpo, and Regoplant, Radostim-super created at the Institute of Bioorganic Chemistry and Petrochemistry, NAS of Ukraine in association with National Enterprise Interdepartmental Science and Technology Center "Agrobiotech" of the NAS and the Ministry of Education, Science and Sport of Ukraine (Iutynska, 2012; Tsygankova, Ponomarenko et al., 2012; Tsygankova, Stefanovska, Galkin et al., 2012; Tsygankova, Andrusevich, Beljavskaja et al., 2012; Tsygankova, Stefanovska, Andrusevich et al., 2012).

Aims of the present work are: a) study of impact of new natural biostimulants on morpho-physiological signs of resistance of sugar beet, cucumber and potato plants to parasitic nematodes: Heterodera schachtii, Meloidogyne incognita and Ditylenchus destructor in the field, greenhouse and laboratory conditions, b) determination of degree of homology between mRNA and si/miRNA populations, isolated from sugar beet, cucumber and potato plants, which were untreated and treated with biostimulants and infected by parasitic phytonematodes Heterodera schachtii, Meloidogyne incognita and Ditylenchus destructor, and c) investigation of silencing activity of si/miRNA populations, isolated from untreated and treated with biostimulants plants, on translation mRNA, isolated from infected plants and from parasitic nematodes, in the wheat embryo cell-free system of protein synthesis.

\section{Materials and Methods}

\subsection{Plant Growing and Treatment}

In our greenhouse, field and laboratory molecular-genetic experiments the sugar beet Beta vulgaris L., cucumber Cucumis sativus of cultivar Gravina and potato Solanum tuberosum of cultivar Bellarosa plants infected by the parasitic nematode Heterodera schachtii Shmidt, gallic nematode Meloidogyne incognita Chitwood and stem nematode of potato Ditylenchus destructor Thome respectively were used.

We investigated bioprotective anti-nematodic effects of new polycomponent biostimulants Avercom and its derivatives (contain metabolites of the soil streptomycete Streptomyces avermitilis UCM Ac-2179, i.e. antiparasitic antibiotic avermectine, aminoacids, free fatty acids, vitamins of the B group, and phytohormones: indole-3-acetic acid, isopentenyl adenine, zeatin, zeatin riboside, brassinosteroids) (Iutynska, 2012; Tsygankova, Andrusevich, Beljavskaja et al., 2012); Radostim-super (contains antiparasitic antibiotic aversectine C metabolites of the soil streptomycete $S$. avermitilis and metabolites, i.e. aminoacids, fatty acids, polysaccharides, phytohormones, and microelements, of cultivated in vitro micromycete Cylindrocarpon obtusiuscuilum 680, isolated out of Panax ginseng root system) (Tsygankova, Stefanovska, Galkin et al., 2012; Tsygankova, Stefanovska, Andrusevich et al., 2012).

Experimental plants growing at laboratory, greenhouse and field conditions were treated by biostimulants Avercom and Radostim-super. Avercom was obtained by ethanol extraction from of 7-days biomass of Streptomyces avermitilis UCM Ac-2179, the concentration of avermectine is $100 \mu \mathrm{g} / \mathrm{ml}$, its derivates: Avercom nova- 1 contains $50 \mathrm{ml}$ of Avercom with antibiotic avermectine at concentration $100 \mu \mathrm{g} / \mathrm{ml}$ with adding $50 \mathrm{ml}$ of supernatant of liquid culture Streptomyces avermitilis UCM Ac-2179 and $0.05 \mathrm{mM}$ of salicylic acid; total content of avermectine is $50 \mu \mathrm{g} / \mathrm{ml}$; and Avercom nova-2 contains $50 \mathrm{ml}$ of Avercom with antibiotic avermectine in concentration $100 \mu \mathrm{g} / \mathrm{ml}$ and $50 \mathrm{ml}$ of supernatant of liquid culture Streptomyces avermitilis UCM Ac-2179 and $0.01 \mathrm{mM}$ of water-soluble chitosan of "Sigma" company; the total concentration of avermectine is $50 \mu \mathrm{g} / \mathrm{ml}$.

Sugar beet and cucumber seeds were sprouted in Petri dishes $(9.5 \mathrm{~cm}$ in diameter) in nematode-free aqueous medium (control) or with a suspension of nematodes $H$. schachtii and $M$. incognita eggs (at the concentration of 20-50 nematode eggs/ 20 seeds). The seeds were incubated at $23{ }^{\circ} \mathrm{C}$ and the nematode larvae hatched in 5-7 days later in average. Each experiment performed in three replicates. In experiments with sugar beet and cucumber seeds we used 4 variants: 1) seeds incubated on aqueous medium (control), 2) seeds incubated on aqueous medium with biostimulant Radostim-super (at the concentration of $25 \mu \mathrm{l} / \mathrm{ml}$ distilled water with final content of aversectine $\mathrm{C}-0.025 \mu \mathrm{g} / \mathrm{ml}$ ) and with biostimulant Avercom (at the concentration of $25 \mu \mathrm{l} / \mathrm{ml}$ distilled water with final content of avermectine $-0.05 \mu \mathrm{g} / \mathrm{ml}$ ), 3) seeds incubated on aqueous medium with a suspension of nematode eggs, 4) seeds incubated on aqueous medium with biostimulant Radostim-super (at the concentration of $25 \mu \mathrm{l} / \mathrm{ml}$ distilled water with final content of aversectine C $-0.025 \mu \mathrm{g} / \mathrm{ml}$ ) and with biostimulant Avercom (at the concentration of $25 \mu \mathrm{l} / \mathrm{ml}$ distilled water with final content of avermectine $-0.05 \mu \mathrm{g} / \mathrm{ml}$ ) and a suspension of nematode eggs.

Cucumber plants of cultivar Gravina were also growing at greenhouse conditions at a background of artificial contamination with nematode $M$. incognita in a quantity of 700 larvae and eggs in $100 \mathrm{~cm}^{3}$ of soil sample. 7 days after the contamination hollows were made in the substratum, in which $100 \mathrm{ml}$ of $2 \%$ solutions of each 
biostimulants were added; after 2 days the seedlings were planted, roots of seedlings were immersed into solutions of biostimulants for 5 minutes before planting. Damage caused by nematodes was scored in points according to methodical guidelines (Sigareva, 1986).

Investigations with potato of cultivar Bellarosa were carried out in field conditions as little-strip experiments with natural and artificial invasive background, created by planting into hollows $50 \mathrm{~g}$ of potato tubers infectected previously by nematode $D$. destructor larvae. Potato plants were treated by biostimulants in the next concentrations: for cultivation of 1 tone of planting material 0.41 of Avercom or its derivates were dissolved in 201 of water.

All the experiments were performed in four replicates.

\subsection{Identification of Degree of Homology Between si/miRNA and mRNA Populations}

Degree of homology between cytoplasmic mRNA and small regulatory si/miRNA populations, isolated from control and experimental plants was determined in the molecular-genetic experiments using Dot-blot hybridization method (Maniatis et al., 1982). Isolation of total RNA from plant cells and separation of high-purity si/miRNA preparations were carried out by our earlier published method (Tsygankova, Andrusevich et al., 2011; Tsygankova, Stefanovska, Andrusevich et al., 2012), the size (of 21-25 nt) of isolated si/miRNA preparations was verified by electrophoresis in a 15\% polyacrylamide gel (Maniatis et al., 1982).

Plant si/miRNA labeled in vivo with ${ }^{33} \mathrm{P}$ using $\mathrm{Na}_{2} \mathrm{HP}^{33} \mathrm{O}_{4}$ before isolation was later used for Dot-blot hybridization with own plant mRNA and with nematode mRNA (Tsygankova, Andrusevich, Beljavskaja et al., 2012; Tsygankova, Stefanovska, Andrusevich et al., 2012). Hybridization was conducted on modified and activated cellulose filters (Whatman 50, 2-aminophenylthioether paper of Company Amersham-Pharmacia Biotech, UK) that form covalent linkages with deposited DNA or RNA unlike the cellulose and nitrocellulose filters that form hydrogen bonds with DNA or RNA enabling to avoid losses of the nucleic acids in the course of the filter washing out (Maniatis et al., 1982).

Radioactivity of hybrid molecules was detected (imp/count per min/20 $\mu \mathrm{g} \pm \mathrm{SE}$ of mRNA) on glass Millipore AP-15 filter in toluene scintillator using Beckman LS 100C scintillation counter. Degree of homology (\%) was determined according to the difference of hybridization between mRNA and si/miRNA from experimental plants and control plants (Tsygankova et al., 2010; Tsygankova, Stefanovska, Andrusevich et al., 2012).

\subsection{Determination of Silencing Activity of si/miRNA Populations in the Cell-Free System of Protein Synthesis}

Investigation of silencing activity of si/miRNA, isolated from untreated and treated by biostimulants plants, on translation of own plant mRNA or nematode mRNA, was conducted in the wheat embryo cell-free system of protein synthesis, which preparation is described in details elsewhere (Marcus et al., 1974; Tsygankova et al., 2010). Reagents of different companies, namely Amersham-Pharmacia Biotech, UK; New England Biolab, USA; Promega Corporation Inc, USA and Boehringer, Dupont, NEN, USA and Mannheim GmbH, Germany were used for preparation of cell free-system. Determination of inhibition by si/miRNA of protein synthesis on the templates own plant mRNA or nematode mRNA in the cell-free system was carried out according to index of decreasing of incorporation $\left[{ }^{35} \mathrm{~S}\right]$ methionine into proteins and was accounted (in imp./count per $\mathrm{min} / 1 \mathrm{mg}$ of protein) on glass filter Millipore AP-15 in toluene scintillator in the scintillation counter LS 100C. Unlabelled si/miRNA were used for testing of inhibitory activity of si/miRNA in the cell-free system of protein synthesis. The silencing activity of si/miRNA (\%) was determined as a difference of radioactivity of polypeptides (count per $\mathrm{min} / 1 \mathrm{mg}$ of protein) synthesized on template mRNA by experimental plants compared to control plants.

The statistical analysis of the data was carried out by dispersive (Student) method (Bang et al., 2010). The least substantial difference $\left(\mathrm{LSD}_{0.05}\right)$ was also calculated for the field experiments (Dospechov, 1985).

\section{Results}

\subsection{Investigation of Morpho-Physiological Signs of Plant Resistance to Parasitic Nematodes Under Impact of Natural Biostimulants}

Biometric researches showed that in the experiments with cucumber plants, which were grown at greenhouse conditions on artificial infectious background created by nematode $M$. incognita, at the end of vegetation period the height of cucumber plants, treated (pre-sowing treatment of seeds and crop spraying) with biostimulant Avercom and its derivatives, exceeds the height of control plants by 10-24\% (Table 1). The highest height of the plants was obtained at their treatment by biostimulant Avercom nova-1. The analysis of plant damage by nematodes showed that the plant damage by nematode $M$. incognita reached up to 3.4 points on the control plot. At the same time for cucumber plants treated by biostimulants, considerable decrease of contamination by 
nematode $M$. incognita (to $29.4 \%$ on an artificial background) was observed. In the case of Avercom plant damage by nematodes was not observed, in the case of Avercom derivatives the plant damage was less than 0,2 1,0 points.

Table 1. Biometric characteristics and degree of damage by nematodes of cucumber plants treated with biostimulants

\begin{tabular}{cccc}
\hline Experience variant & \multicolumn{2}{c}{ Height of plants } & Damage of plants by nematode \\
\cline { 2 - 3 } & $\mathrm{cm}$ & \% in relation to control & M.incognita, (in point) \\
\hline $\begin{array}{c}\text { Control (without use of } \\
\text { biostimulants) }\end{array}$ & $168 \pm 5.9$ & 100 & 3.4 \\
Avercom & $197 \pm 6.9$ & 117 & 0.2 \\
Avercom nova-1 & $208 \pm 7.3$ & 124 & 1.0 \\
Avercom nova-2 & $184 \pm 6.4$ & 110 & 0.2 \\
\hline
\end{tabular}

We have also studied the impact of biostimulants on plant productivity. The yield of cucumbers treated by Avercom and its derivatives was 16-26\% higher compared to control. The highest yield was obtained when the plants were treated with Avercom (Table 2).

Table 2. The yield of cucumber plants treated with biostimulants

\begin{tabular}{cccc}
\hline Experience variant & Yield, $\mathrm{kg} / \mathrm{m}^{2}$ & \multicolumn{2}{c}{ Yield increase } \\
\cline { 3 - 4 } & & $\mathrm{kg} / \mathrm{m}^{2}$ & $\%$ in relation to control \\
\hline $\begin{array}{c}\text { Control (without use of } \\
\text { biostimulants) }\end{array}$ & 6.8 & 0 & 100 \\
Avercom & 8.6 & 1.8 & 126 \\
Avercom nova-1 & 8.3 & 1.5 & 122 \\
Avercom nova-2 & 7.9 & 1.1 & \\
LSD $_{0.05}$ & 0.2 & & \\
\hline
\end{tabular}

In the experiments with potato plants, which were carried out on a natural invasive background and artificial background, created by potato stem nematode $D$. destructor, it was shown that pre-sowing treatment of potato tubers and crop spraying with biostimulants Avercom and its derivatives decreased damage of potato tubers by dytylenchosis and increased crops productivity (Table 3 ). 
Table 3. Damage of potato by ditylenchosis and productivity of potato plants under various conditions of growing

\begin{tabular}{|c|c|c|c|c|}
\hline \multirow[b]{2}{*}{ Experiment } & \multicolumn{2}{|c|}{ Damage of plants by ditylenchosis } & \multicolumn{2}{|c|}{ Productivity of crops } \\
\hline & $\begin{array}{c}\text { Quantity of sick potato } \\
\text { tubers, } \%\end{array}$ & $\begin{array}{c}\text { Biological } \\
\text { efficiency of } \\
\text { biostimulants }\end{array}$ & $\begin{array}{c}\text { Yield, } \\
\text { pounds/ha }\end{array}$ & $\begin{array}{c}\text { Yield increase }(\%) \\
\text { in relation to } \\
\text { control }\end{array}$ \\
\hline \multicolumn{5}{|c|}{ Natural background } \\
\hline $\begin{array}{l}\text { Control (without use } \\
\text { of biostimulants) }\end{array}$ & 40.1 & - & 36375.9 & 0 \\
\hline Avercom & 11.8 & 70.5 & 40785.1 & 12.1 \\
\hline Avercom nova-1 & 24.7 & 38.4 & 37478.2 & 3.0 \\
\hline Avercom nova-2 & 34.4 & 14.2 & 38580.5 & 6.1 \\
\hline $\operatorname{LSD}_{0.05}$ & 5.1 & - & 1763.7 & \\
\hline \multicolumn{5}{|c|}{ Artificial invasion background } \\
\hline \multicolumn{5}{|l|}{ Control (without } \\
\hline use of & 48.0 & - & 33950.8 & 100 \\
\hline \multicolumn{5}{|l|}{ biostimulants) } \\
\hline Avercom & 21.5 & 55.2 & 37478.2 & 10.4 \\
\hline Avercom nova-1 & 34.0 & 29.2 & 36596.4 & 7.8 \\
\hline Avercom nova-2 & 44.0 & 8.3 & 35494.1 & 4.5 \\
\hline $\operatorname{LSD}_{0.05}$ & 5.1 & - & 1543.2 & \\
\hline
\end{tabular}

We have obtained the considerable decrease of contamination (to $26.5 \%$ on an artificial background) of potato plants by nematode $D$. destructor. Biological efficiency of Avercom reached more than $70 \%$ in experiments on a natural nematodic background and $55 \%$ on artificial invasion background created by nematodes, the less biological efficacy showed by Avercom nova-1 - 38.4\% and 29.2\%.

Impact of the biostimulants on potato productivity was also studied. Biostimulants promoted increase in potato productivity up to $12.1 \%$ - on natural nematode infection and up to $10.4 \%$ - in conditions of artificial infection.

On natural invasive background the most statistically significant increase in productivity (up to $12.1 \%$ compared to the control) of potato was achieved at pre-sowing planting material treatment with Avercom. On artificially created invasive background Avercom promoted the increasing of yield of potato by $10.4 \%$.

Similar experiments devoted to impact of biostimulant Radostim-super on morpho-physiological signs and productivity of winter wheat plants have been conducted by us early in field conditions (Figure 1) (Sweere et al., 2011). Results obtained in these experiments testify about positive influence of biostimulant Radostim-super on dynamics of growth and increase of productivity of winter wheat. We conducted similar experiments on other agricultural plants; the considerable increase of photosynthetic activity (i.e. assimilation of $\mathrm{CO}_{2}$ by plants) was obtained when plants were treated by biostimulant Radostim-super: rye (up to $12.5 \%$ ), barley (up to $10.3 \%$ ), oats (up to $13.7 \%$ ), millet (up to $11.4 \%$ ) corn (up to $12.9 \%$ ), rice (up to $13.2 \%$ ), buckwheat (up to $10.7 \%$ ) (Sweere et al., 2011). Considerable increase of productivity of these crops from $20 \%$ to $65 \%$ under the impact of biostimulant Radostim-super was found in these investigations. 
Effect of biostimulant Radostim-super on structural and morphological characteristics and productivity of winter wheat

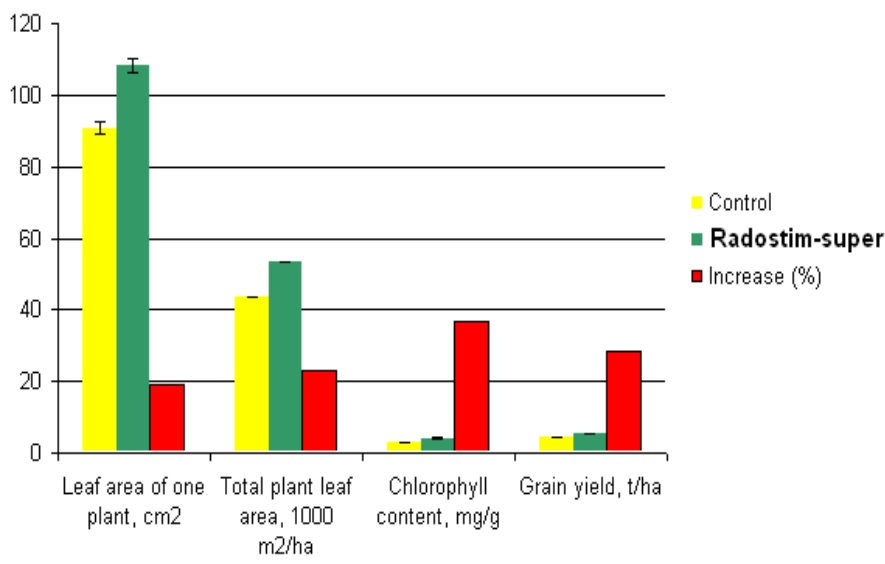

Figure 1. Impact of biostimulant Radostim-super on morpho-physiological signs and productivity of winter wheat plants grown under field conditions (seeds of winter wheat were treated before sowing with biostimulant Radostim-super at the concentration of $25 \mathrm{ml} / \mathrm{t}$ of seeds)

We have also tested in the field and greenhouse conditions the bioprotective effects of biostimulant Radostim-super against sugar beet nematode H. schachtii (Tsygankova, Stefanovska, Galkin et al., 2012). We have shown that treatment of sugar beet seeds and spraying of crops in vegetation period by Radostim-super considerably decreases the sugar nematode population density in the soil by $74.2 \%$, whereas in control experiments (seeds treated by water) the beet nematode number in soil increased by $22 \%$. In addition to the reduction in nematode numbers, the application of Radostim-super increased the sugar beet yield and sugar yield which were significantly higher than in the control by 40.0 and 6.2 tons/ha, respectively (Tsygankova, Stefanovska, Andrusevich et al., 2012; Tsygankova, Stefanovska, Galkin et al., 2012).

It was found in the laboratory experiments (Figure 2 and Figure 3 ) that 5 -day sugar beet sprouts (obtained from seeds infected by nematode $H$. schachtii and treated with biostimulant Radostim-super) and 5-day cucumber sprouts (obtained from seeds infected by nematode $M$. incognita and treated with biostimulant Avercom) were more viable and resistant to these nematodes as compared to control sprouts (infected by nematodes and untreated with biostimulants). 

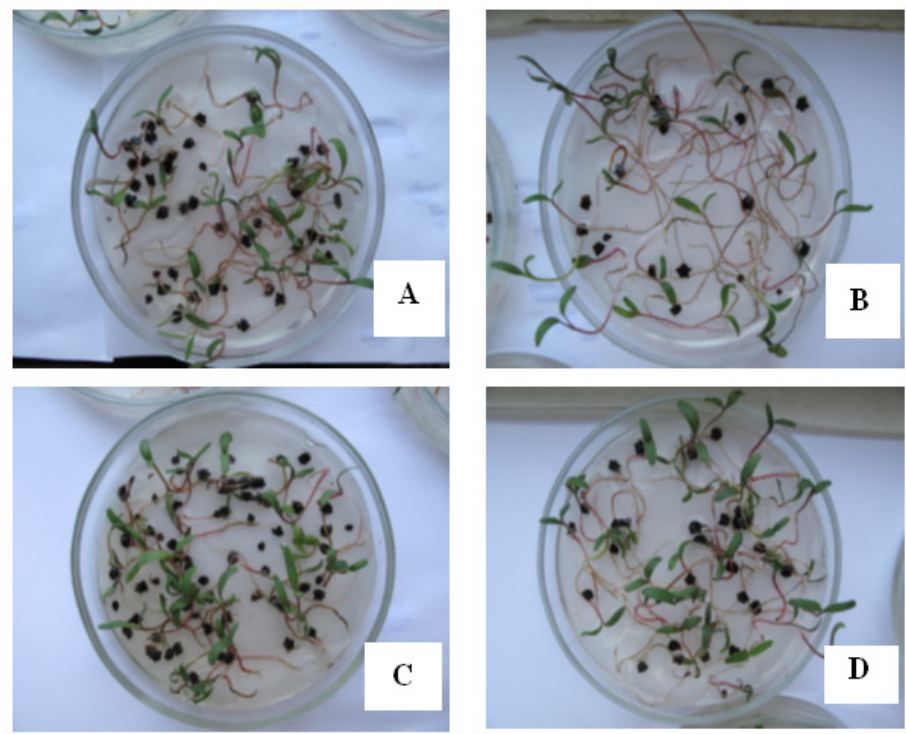

Figure 2. Impact of biostimulant Radostim-super on germination of sugar beet Beta vulgaris L. seeds and development of sprouts

A) 5-day sprouts grown on distilled water (control); B) 5-day sprouts grown on infectious background, created by parasitic nematode H. schachtii; C) 5-day sprouts treated with Radostim-super and grown on infectious background, created by parasitic nematode H. schachtii; D) 5-day sprouts treated with Radostim-super and grown without infectious background.
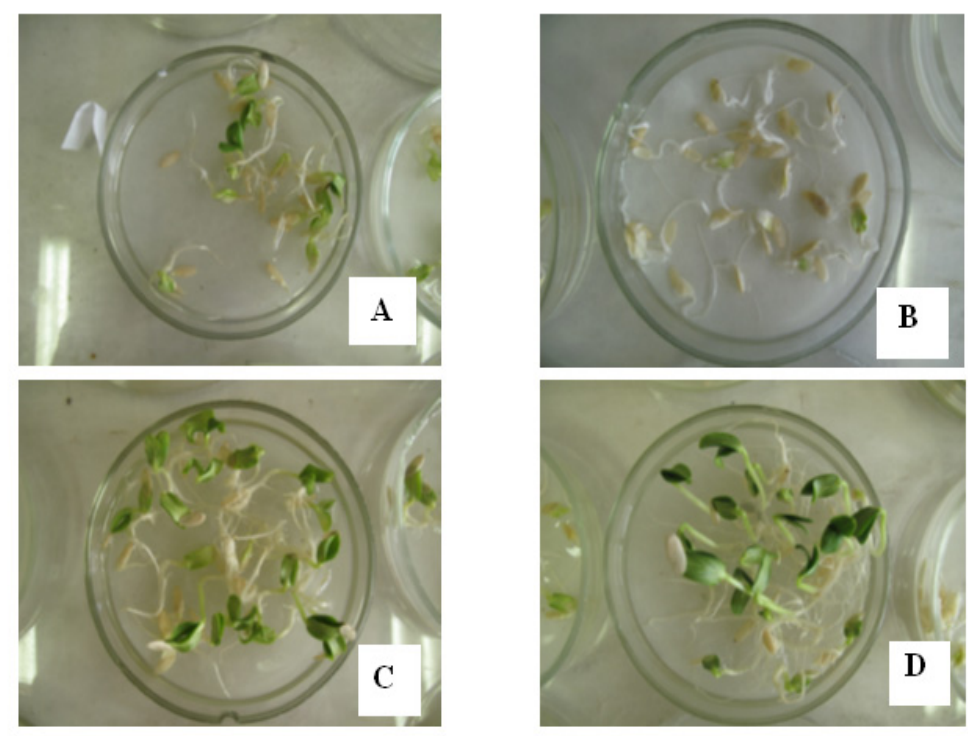

Figure 3. Impact of biostimulant Avercom on germination of cucumber seeds of cultivar Gravina and development of sprouts

A) 5-day sprouts grown on distilled water (control); B) 5-day sprouts grown on infectious background created by parasitic nematode M. incognita; C) 5-day sprouts treated with Avercom and grown on infectious background, created by parasitic nematode M. incognita; D) 5-day sprouts treated with Avercom and grown without infectious background.

3.2 Impact of Biostimulant Radostim-Super on Changes in the Degree of Homology Between si/miRNA and $m R N A$, and on Silencing Activity of si/miRNA

Changes in the level of si/miRNA synthesis (according to degree of homology between si/miRNA and mRNA) 
in the control plants, in the plants treated by Radostim-super, in the plants incubated with nematode $H$. schachtii and in the plants infected by nematode $H$. schachtii and treated with Radostim-super were determined using Dot-blot hybridization method.

Radioautographs on cellulose filters of probes which are hybrid molecules of mRNA isolated from control plants with $\left[\mathrm{P}^{33}\right]$-si/miRNA isolated from experimental plants treated by biostimulants and grown without infectious background are presented in Figure 4.

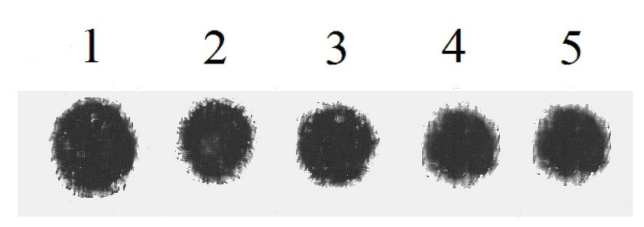

Figure 4. Radioautographs on cellulose filters of probes (hybrid molecules of mRNA from control plants with $\left[\mathrm{P}^{33}\right]$-si/miRNA from experimental plants)

1) mRNA and si/miRNA from control plants; 2) mRNA from control plants and si/miRNA from sugar beet plants, treated with biostimulant Radostim-super; 3) mRNA from control plants and si/miRNA from cucumber plants, treated with biostimulant Avercom; 4) mRNA from control plants and si/miRNA from cucumber plants, treated with biostimulant Avercom nova-1; 5) mRNA from control plants and si/miRNA from cucumber plants, treated with biostimulant Avercom nova-2.

It is shown in Figure 5 that according to degree of homology between populations of mRNA and si/miRNA Radostim-super considerably increased the synthesis of si/miRNA in plants not infected by nematodes, but on the contrary in plants infected by nematodes and untreated with this biostimulant the synthesis of si/miRNA is sharply reduced. Biostimulant Radostim-super increases si/miRNA synthesis in infected plants, but in these plants the level of synthesis is lower compared with level of synthesis in plants not infected by nematodes and not treated with this biostimulant.

\section{Increase of antinematode properties of si/miRNA of 5-day sugar beet sprouts under impact of Radostim-super and} nematode Heterodera schachtii larvae

$\square$ Hybrids of mRNA with P33 si/miRNA of control plants

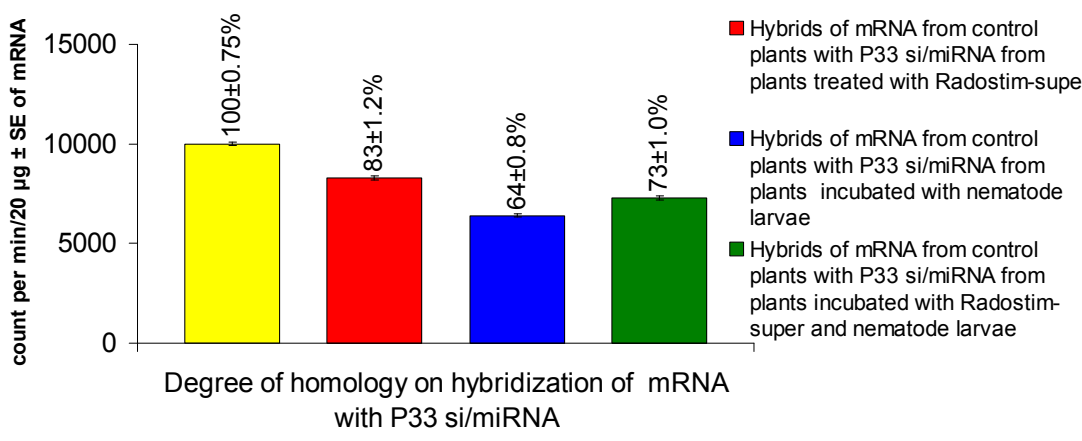

Figure 5. The degree of homology (\%) between populations of mRNA and si/miRNA from control and experimental sugar beet plants infected by nematode larvae and treated with biostimulant Radostim-super

Investigation of inhibitory (silencing) activity of si/miRNA on the template of mRNA from plants in the wheat embryo cell-free system of protein synthesis showed (Figure 6) that si/miRNA, isolated from plants not infected by nematodes and treated with Radostim-super, showed high inhibitory activity ( $82 \%)$, close to those of control plants $(100 \%)$. Obtained results testify that this biostimulant changes si/miRNA population in plant cells. 


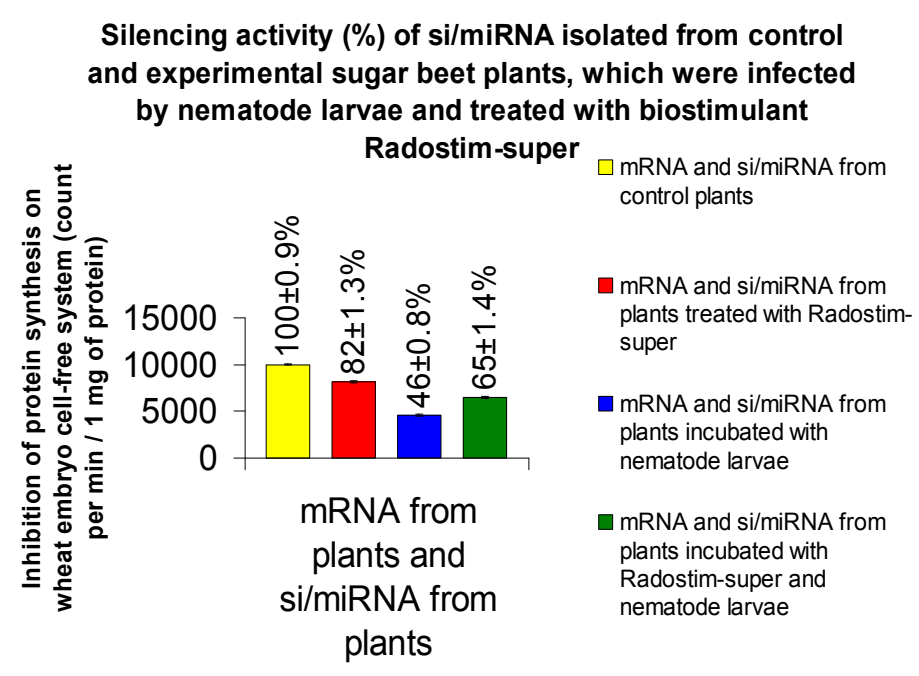

Figure 6. Inhibition of protein synthesis in the wheat embryo cell-free system on the template of mRNA from control and experimental plants by si/miRNA from control and experimental sugar beet plants infected by nematode larvae and treated with biostimulant Radostim-super

The inhibitory activity of si/miRNA, isolated from the same plants, treated by biostimulant, on the template mRNA from nematode larvae (Figure 7) was slightly higher (15\%) than that of control si/miRNA, isolated from untreated plants (10\%). This shows insignificant homology between plant si/miRNA and nematode mRNA.

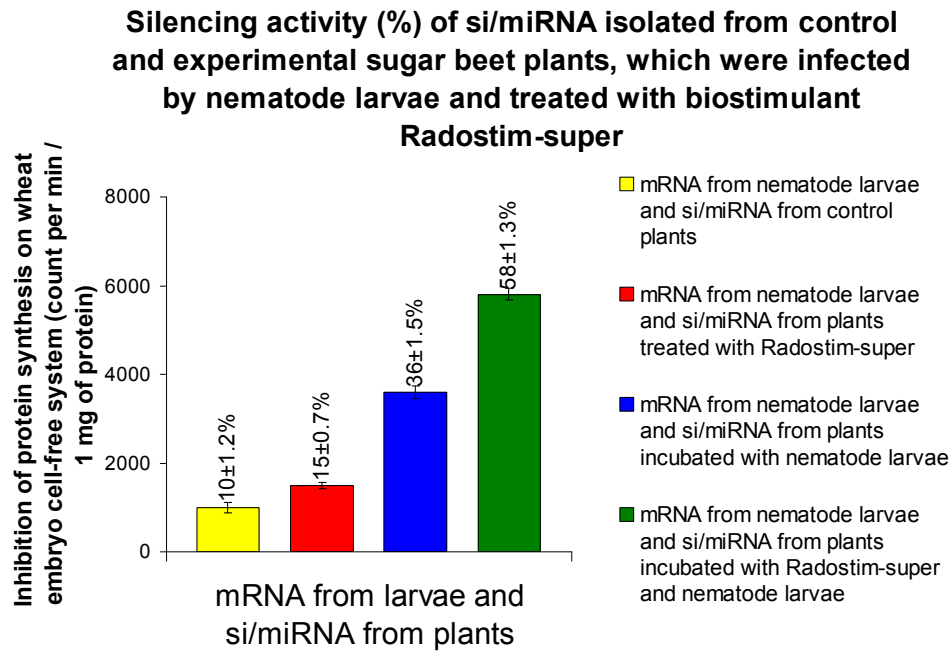

Figure 7. Inhibition of protein synthesis in the wheat embryo cell-free system on the template of mRNA from nematode larvae by si/miRNA from control and experimental sugar beet plants infected by nematode larvae and treated with biostimulant Radostim-super

At the same time (Figure 6 and Figure 7) the inhibitory activity of si/miRNA, isolated from plants, infected by nematode larvae and treated by Radostim-super, considerably increased both on the template of mRNA from the same plants (65\%) and on template of mRNA from nematode larvae $(58 \%)$.

At the same time inhibitory activity of si/miRNA, isolated from plants infected by nematode larvae and untreated by biostimulant, was lower both on the template of mRNA from plants $(46 \%)$ and on the template of mRNA from nematode larvae $(36 \%)$. 
Obtained results confirm that biostimulant Radostim-super causes reprogramming of plant genome to induce synthesis of si/miRNA specific (antisence) both to own plant mRNA (which expression promotes infection) and to homologous mRNA of nematodes.

\subsection{Impact of Biostimulant Avercom and Its Derivatives on Homology Between si/miRNA and mRNA, and on Silencing Activity of si/miRNA}

Radioautographs on cellulose filters of probes which are hybrid molecules of mRNA isolated from control plants with $\left[\mathrm{P}^{33}\right]$-si/miRNA isolated from experimental plants treated by biostimulants and grown without infectious background are presented above in Figure 4.

Data for the analysis of degree of homology between populations of cytoplasmic mRNA and si/miRNA, isolated from control and experimental potato plants and cucumber, which were grown in greenhouse and field conditions on an artificial infectious background and treated with biostimulant Avercom and its modifications, are presented in Figure 8.

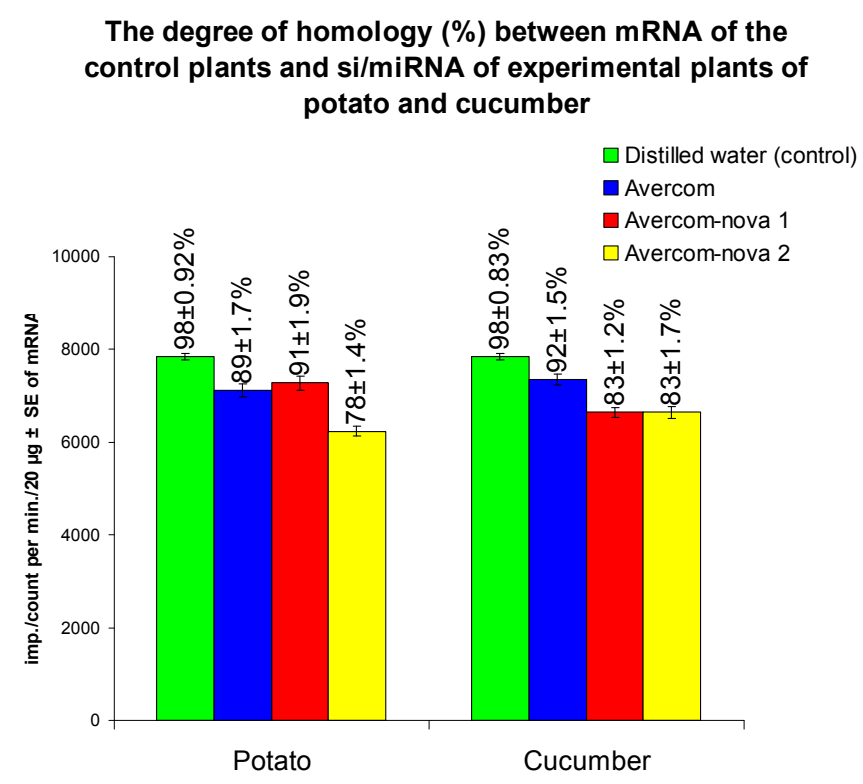

Figure 8. Degree of homology (\%) between mRNA of the control plants and si/miRNA of the control and experimental potato and cucumber plants treated with biostimulants and infected by parasitic gallic nematode $M$. incognita and stem nematode of potato $D$. destructor

Comparative analysis of degree of homology (\%) between si/miRNA and mRNA (Figure 8) obtained in the experimental plants compared to the same values in the control plants, showed that the largest difference in the degree of homology regarding to control plants was observed in experimental plants treated with biostimulants Avercom nova-2 (up to $20 \%$ - in potato and up to $15 \%$ - in cucumber plants) and Avercom nova-1 (up to $15 \%$ in cucumber and up to $7 \%$ - in potato plants), smaller difference in the degree of homology was found in the experimental plants treated with biostimulant Avercom (up to $6 \%$ - in cucumber and $9 \%$ - in potato plants).

According to experiments in the wheat embryo cell-free system of protein synthesis, results of inhibition of the translation of mRNA from the cucumber and potato plants infected with nematodes $M$. incognita and $D$. destructor and treated with biostimulant Avercom and its derivates show significant increase of silencing activity of si/miRNA (similar to activity of si/miRNA from not infected plants - control N1) isolated from cucumber and potato plants infected by nematodes $M$. incognita and $D$. destructor and treated with these biostimulants (Figure 9). 


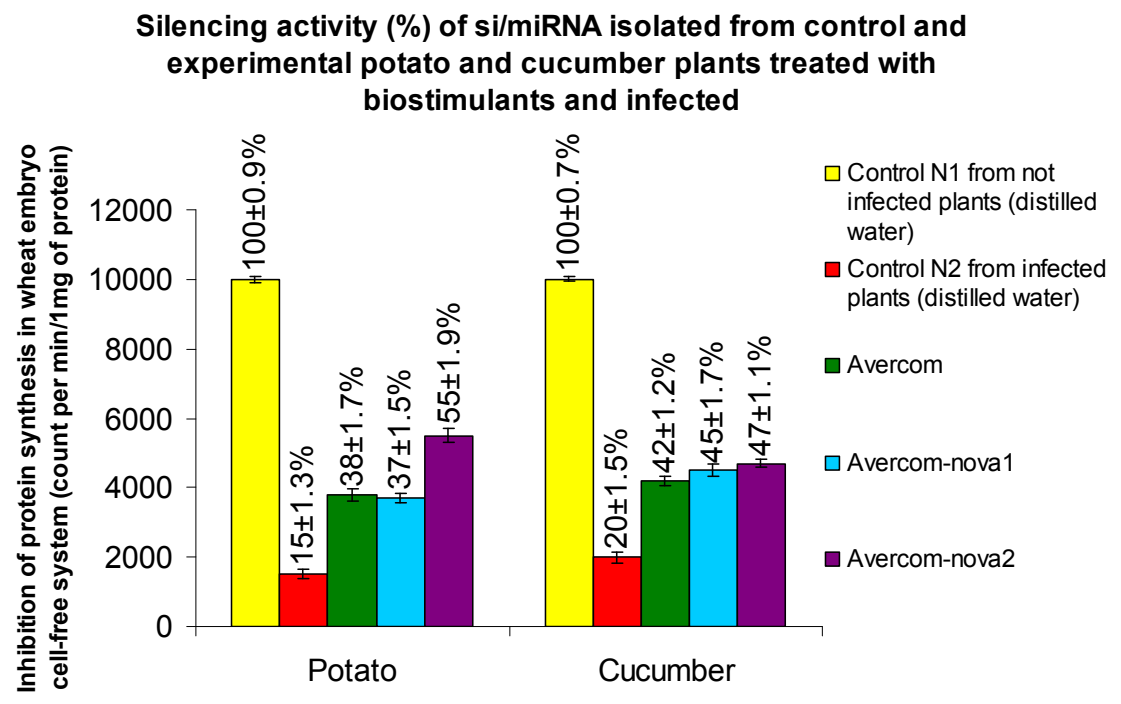

Figure 9. Inhibition of protein synthesis in the wheat embryo cell-free system on the template of mRNA from control and experimental plants by si/miRNA from control and experimental potato and cucumber plants treated with biostimulants and infected by parasitic gallic nematode M. incognita and stem nematode of potato $D$. destructor

According to results of inhibition of the translation of mRNA from cucumber and potato plants infected with nematodes $M$. incognita and $D$. destructor the highest silencing activity (compared to control $\mathrm{N} 1$ ) was shown by si/miRNA isolated from the same plants treated with biostimulants (Figure 9) Avercom nova-2 (up to 55\% - in potato and up to $47 \%$ - in cucumber plants) and Avercom nova-1 (up to $45 \%$ - in cucumber and up to $37 \%$ - in potato plants), the lower silencing activity was shown by si/miRNA isolated from experimental plants treated with Avercom (up to $42 \%$ - in cucumber and up to $38 \%$ - in potato plants). Significantly lower silensing activity (up to $15 \%$ - in potato, up to $20 \%$ - in cucumber plants) was shown by si/miRNA, isolated from infected plants, which were untreated with biostimulants (control N 2).

\section{Discussion}

Existing methods for controlling the distribution of nematodes and the reduction in the yield of important crops caused by them are chemically synthesized soil fumigants, nematicides (belonging to the classes of organophosphates and carbamates), and various types of insecticides of natural origin, for example, phytoinsecticide pyrethryn and its synthetic analogs, i.e., pyrethroids (Mitkowski et al., 2003; Oka, 2010; Winter et al., 2006). In most countries worldwide, however, a trend is observed towards practically restricting their use because of their high toxicity to humans and contamination of the environment. Traditional methods to regulate the amount of parasitic nematodes also include various biocontrol technologies, i.e., application of various organic soil fertilisers and industrial waste of vegetable or animal origin, compost, and changes in soil $\mathrm{pH}$ (acidification of up to $\mathrm{pH} 4$ or alcalinization of up to $\mathrm{pH}$ 8); introduction of antagonistic and competitive microorganisms (bacteria of the strains Burkholderia cepacia and Bacillus chitinosporus and the fungi micromycetes Myrothecium verrucaria and Paecilomyces lilacinus) to soil; crop rotation with the development of cultures resistant to nematodes, using biopreparations that contain essential oils of various herbs with an anti-nematodic effect (for example, the oil of sesame, garlic, rosemary, or white pepper); etc. (Oka, 2010). Unfortunately, a combination of the above listed methods can only depress the high viability of this pest class.

Now the success in increasing of plant resistance to nematodes has been reached by genetic engineering and breeding methods (Bleve-Zacheo et al., 2007; Fairbairn et al., 2007; Fuller et al., 2008; Gheysen et al., 2006; Liao et al., 2003; Tsygankova, Andrusevich, Ya, Ponomarenko et al., 2013; Tsygankova, Yemets et al., 2013).

The newer approach for nematode disease management is to increase plant resistance against agricultural pests by new ecologically safe plant growth regulators of natural or synthetic origin, phythohormones, seaweed and plant extracts, and organic compounds (such as sugar or ascorbic acid). In favor of this new approach testify numerous studies (Acquaah, 2007; Aktaruzzaman et al., 2012; Arrigoni et al., 1979; Bleve-Zacheo et al., 2007; Dias-Arieira et al., 2013; Fortum et al., 1983; Khan et al., 2009; Mitkowski et al., 2003; Moghaddam et al., 2012; 
Olaiya et al., 2013; Tsygankova, Andrusevich et al., 2012; Tsygankova, Andrusevich et al., 2013; Verhage et al., 2010).

For example, the impact of five commercial products marketed as systemic resistance (SR) and plant growth promotion (PGP) inducers on increase of tomato plant (Lycopersicon esculentum Mill.) resistance to pathogenic bacteria or nematodes in greenhouse conditions has been studied by Vavrina et al., 2004.

These SR/PGP inducers included a bacterial suspension [Companion (Bacillus subtilis GB03)], two plant defense elicitors with nutrients (Keyplex 35ODP plus Nutri-Phite, and Rezist with Cab'y), natural plant extracts (Liquid Seaweed Concentrate and Stimplex), and synthetic growth regulator (Actigard 50W). Comparative analysis of growth stimulating and bioprotective effects of SR/PGP inducers have shown that highest suppression of bacterial spot [Xanthomonas campestris pv. vesicatoria $(\mathrm{Xcv})]$ is caused by synthetic regulator Actigard. Other SR/PGP inducers: Companion, Keyplex 35ODP plus Nutri-Phite, Rezist, Cab'y, Liquid Seaweed Concentrate and Stimplex induced only partial suppression of bacterial spot in inoculated tomato plants. The alpha-keto acids plus nutrients (Keyplex 35ODP plus Nutri-Phite) increased plant growth by $14.3 \%$ and improved root condition compared to untreated control following exposure to nematodes.

In the present work, we investigated the impact of biostimulants on inducing of RNA-interference process (RNAi or PTGS) in plant cells, i.e. increasing synthesis of si/miRNA with immune-protective anti-nematodic properties. We studied genetic mechanisms of increase of sugar beet, cucumber and potato plant resistance to parasitic nematodes $H$. schachtii, M. incognita and D. destructor under impact of biostimulants: Radostim-super, Avercom and its derivatives. The experiments we based on the assumption that plants, infected with different types of pathogenic or parasitic organisms, increased the synthesis of si/miRNA specific both to own plant mRNA (which expression rises at the specialized infected plant cells and involves plant developmental processes) and to pathogenic or parasitic highly homologous mRNA (Hewezi et al., 2008; Ithal et al., 2007; Katiyar-Agarwal et al., 2006; Klink et al., 2009; Li et al., 2012; Padmanabhan et al., 2009; Patel et al., 2010). We also assumed that the biostimulants induce synthesis of si/miRNA which improves plant immunity through the specified mechanism of si/miRNA action.

We need to be sure that our assumptions are correct, so that a new generation of biostimulants with the properties of selective activation of synthesis of si/miRNA, which is specific to own plant cell mRNA or to pathogenic or parasitic highly homologous mRNA can be created. Thus we verified the changes in the populations of si/miRNA (according to degree of homology between si/miRNA and mRNA) and compared silencing activity of si/miRNA from biostimulant-treated and untreated plants. The conciderable differences obtained in these experiments in the degree of homology between si/miRNA and mRNA from control and experimental plants and high silencing activity of si/miRNA from plants, which were treated with biostimulants, testify about impact of these biostimulants on reprogramming of plant genome to induce synthesis of immune-protective si/miRNA in plant cells. As a result the resistance of plants to parasitic nematodes considerably rises.

The results of this work correlate and supplement the data of our previous experiments, in which we have conducted numerous investigations on various agricultural plants like rape, wheat, chickpea, corn and soybean, which were grown on invasion background created by pests: ground beetle, Zabrus tenebrioides, turnip moth Scotia segetum and Chloropidae spp.; pathogenic micromycetes: Mucor spp., Rhizopus spp., Aspergillus spp., Penicillium spp., Trichothecium roseum, Fusarium graminearum, Fusarium oxysporum f. ciceris, Alternaria alternata; phytonematode Anguina tritici (Tsygankova, 2012; Tsygankova, Ponomarenko et al., 2012; Tsygankova, Stefanovska, Andrusevich et al., 2012; Tsygankova, Andrusevich et al., 2011; Tsygankova et al., 2013). In these field and greenhouse experiments we have shown that treatment of plant seeds and spraying of crops in vegetation period by biostimulants of natural origin: Regoplant, Stimpo, Radostim and Radostim-super considerably increased (up to 74-98\%) plant resistance to above mentioned phytopathogens.

Biological efficiency of biostimulant of microbiological origin Avercom and its composition with elicitors was also tested on early wheat, cucumber and tomato crops in field and greenhouse experiments with natural and artificial invasive backgrounds, created by phytonematodes: Tylenchorbynchus dubius, Pratylenchus pratensis, Meloidogyne incognita and by phytopathogenic micromycete Fusarium oxysporum (Iutynsk $a$ et al., 2011; Tsygankova, Galkin et al., 2011; Tsygankova, Andrusevich, Beljavskaja et al., 2012). High antagonistic activity of biostimulants against all specified phytopathogens was found in the experiments. The plants treated with these biostimulants showed considerably increased resistance (up to $85-100 \%$ ) to specified phytopathogens.

The molecular-genetic experiments, which were conducted in all these works, showed that increased plant resistance to phytopathogens is caused by inducing effect of these biostimulants on synthesis in plants of si/miRNA immune-protective against nematodes. 


\section{Conclusion}

It was found that in the field, greenhouse and laboratory experiments according to morpho-physiological signs of plants the application of new natural biostimulants: Radostim-super, Avercom and its derivates (containing bioprotective substances - aversectine and avermectine) leads to considerable increase of resistance of sugar beet, cucumber and potato plants to nematodes $H$. schachtii, M. incognita and D. destructor.

In the molecular-biological investigations we found conciderable lowering of homology (from 6 to 28\%) between si/miRNA and mRNA populations from experimental (infected by these nematodes and treated with biostimulants) plants and control plants.

These differences in degree of homology may be the result of activation of synthesis of small regulatory si/miRNA with high anti-nematodic activity by biostimulants in plants. Increase of silencing activity of si/miRNA (up to $38-65 \%$ ) of the plants infected by nematodes conforms to this assumption. This effect under the impact of biostimulant Avercom and its derivatives significantly increases plant resistance to parasitic nematodes. Obtained changes in degree of homology between mRNA and si/miRNA populations can be used as genetic markers of increase of plant resistance to phytopathogens.

\section{Acknowledgements}

This research has been carried out with support of the STCU project P490 of National Academy of Sciences of Ukraine and of the project "Molecular bases of creation of biologically active and ecologically safe preparations with bioprotective and immunomodulative properties" of the special purpose complex interdisciplinary program of the scientific researches of National Academy of Sciences of Ukraine "Fundamentals of molecular and cellular biotechnology" (confirmed by the decision of Presidium of National Academy of Sciences of Ukraine from 07.07.10, No. 222).

\section{References}

Acquaah, G. (2007). Principles of Plant Genetics and Breeding (p. 564). Blackwell Publishing Ltd.

Aktaruzzaman, M., Ray, D. B., Hossain, M. F., \& Afroz, T. (2012). Effect of Bau-biofungicide and some plant extracts against root-knot (Meloidogyne javanica) of papaya. Int. J. Sustain. Crop Prod., 7(1), 1-5.

Angaji, S. A., Hedayati, S. S., Hoseinpoor, R., Samadpoor, S., Shiravi, S., \& Madani, S. (2010). Application of RNA interference in plants. Plants Omics Journal, 3(3), 77-84.

Arrigoni, O., Zacheo, G., Arrigoni-Liso, R., Bleve-Zacheo, T., \& Lamberti, F. (1979). Relationship Between Ascorbic Acid and Resistance in Tomato Plants to Meloidogyne incognita. Phytopathology, 69(6), 579-581. http://dx.doi.org/10.1094/Phyto-69-579

Bakhetia, M., Charlton, W. L., \& Urwin, P. E. (2005). RNA interference and plant parasitic nematodes. Trends Plant Sci., 10(8), 362-367. http://dx.doi.org/10.1016/j.tplants.2005.06.007

Bang, H., Zhou, X. K., van Epps, H. L., \& Mazumdar, M. (2010). Statistical Methods in Molecular Biology. Series: Methods in Molecular Biology (p. 636). New York: Humana Press. http://dx.doi.org/10.1007/978-1-60761-580-4

Baum, T. J., Hussey, R. S., \& Davis, E. L. (2007). Root-knot and cyst nematode parasitism genes: the molecular basis of plant parasitism. Genetic Engineering $(N \quad Y), \quad 28, \quad 17-43$. http://dx.doi.org/10.1007/978-0-387-34504-8_2

Bleve-Zacheo, T., Melillo, M. T., \& Castagnone-Sereno, P. (2007). The Contribution of Biotechnology to Root-Knot Nematode Control in Tomato Plants. Pest Technology, Global Science Books, 1(1), 1-16.

Calarco, J. P., Borges, F., Donoghue, M. T. A., Van Ex, F., Jullien, P. E., Lopes, T., ... Martienssen, R. A. (2012). Reprogramming of DNA Methylation in Pollen Guides Epigenetic Inheritance via Small RNA. Cell. http://dx.doi.org/10.1016/j.cell.2012.09.001

Chen, X. (2009). Small RNAs and Their Roles in Plant Development. Annu. Rev. Cell Dev. Biol., 35, 21-44. http://dx.doi.org/10.1146/annurev.cellbio.042308.113417

Dias-Arieira, C. R., Santana-Gomes, S., Puerari, H. H., Fontana, L. F., Ribeiro, L. M., \& Mattei, D. (2013). Induced resistance in the nematodes control. African Journal of Agricultural Research, 8(20), 2312-2318.

Dospechov, B. A. (1985). Technique of field (with a basis of statistical processing of results of researches). ( ${ }^{\text {th }} \mathrm{Ed}$., p. 51). Moscow: Agropromizdat.

Fabian, M. R., Sonenberg, N., \& Filipowicz, W. (2010). Regulation of mRNA Translation and Stability by 
microRNAs. Аnnu. Rev. Biochem., 79, 351-79. http://dx.doi.org/10.1146/annurev-biochem-060308-103103

Fairbairn, D. J., Cavallaro, A. S., Bernard, M., Mahalinga-Iyer, J., Graham. M. W., \& Botella, J. R. (2007). Host delivered RNAi: an effective strategy to silence genes in plant parasitic nematodes. Planta (Vol. 226, pp. 1525-1533). http://dx.doi.org/10.1007/s00425-007-0588-x

Filipowicz, W., Jaskiewicz., L., Kolb, F. A., \& Pillai, R. S. (2005). Post-transcriptional gene silencing by siRNAs and miRNAs. Curr. Opin. Struct. Biol., 15, 331-341. http://dx.doi.org/10.1016/j.sbi.2005.05.006

Fortum, B. A., \& Lewis, S. A. (1983). Effects of growth regulators and nematodes on Cylindrocladium blach root rot of soybean. Plant Desease, 67, 282-284. http://dx.doi.org/10.1094/PD-67-282

Fuller, V. L., Lilley, C. J., \& Urwin, P. E. (2008). Nematode resistance. New Phytol., 180, $27-44$. http://dx.doi.org/10.1111/j.1469-8137.2008.02508.x

Gheysen, G., \& Vanholme, B. (2006). RNAi from plants to nematodes. Trends in Biotechnol., 25(3), 89-92. http://dx.doi.org/10.1016/j.tibtech.2007.01.007

Hammilton, A., Voinnet, O., \& Chapell, L. (2002). Two classes of short interfering RNA in RNA silencing. EMBO J., 21, 4671-4679. http://dx.doi.org/10.1093/emboj/cdf464

Hewezi, T., Howe, P., Mairer, T. R., \& Baum, T. J. (2008). Arabidopsis small RNAs and their targets during cyst nematode parasitism. Mol. Plant-Microbe Interact., 21, 1622-1634. http://dx.doi.org/10.1094/MPMI-21-12-1622

Ithal, N., Recknor, J., Nettleton, D., Hearne, L., Maier, T., Baum, T. J., \& Mitchum, M. G. (2007). Parallel genome wide expression profiling of host and pathogen during soybean cyst nematode infection of soybean. Mol. Plant-Microbe Interact., 20 (3), 293-305. http://dx.doi.org/10.1094/MPMI-20-3-0293

Iutynska, G. A. (2012). Elaboration of natural polyfunctional preparations with antiparasitic and biostimulating properties for plant growing. Mikrobiol. J., 74(4), 3-12.

Iutynska, H. O., Tytova, L. V., Leonova, N. O., Antypchuk, A. F., Brovko, I. S., Eakin, D., ... Pindrus, A. A. (2011). Complex preparations based on microorganisms and plant growth regulators. In S. P. Ponomarenko \& H. O. Iutynska (Eds.), New plant growth regulators: basic research and technologies of application (pp. 161-207). Kyiv: Nichlava.

Katiyar-Agarwal, S., Morgan, R., Dahlbeck, D., Borsani, O., Villegas, A., Zhu, J. K., ... Jin, H. L. (2006). A pathogen-inducible endogenous siRNA in plant immunity, Proc Natl Acad Sci USA, 103(47), 18002-18007. http://dx.doi.org/10.1073/pnas.0608258103

Khan, W., Rayirath, U. P., Subramanian, S., Jithesh, M. N., Rayorath, P., Hodges, D. M, ... Prithviraj, B. (2009). Seaweed Extracts as Biostimulants of Plant Growth and Development. J. Plant Growth Regul., 28, 386-399. http://dx.doi.org/10.1007/s00344-009-9103-x

Klink, V. P., \& Matthews, B. F. (2009). Emerging Approaches to Broaden Resistance of Soybean to Soybean Cyst Nematode as Supported by Gene Expression Studies. Plant Physiology, 151, 1017-1022. http://dx.doi.org/10.1104/pp.109.144006

Lee, Y., Ahn, C., \& Han J. (2003). The nuclear RNase III Drosha initiates microRNA processing. Nature, 425, 415-419. http://dx.doi.org/10.1038/nature01957

Li, X., Wang, X., Zhang, S., Liu, D., Duan, Y., \& Dong, W. (2012) Identification of Soybean MicroRNAs Involved in Soybean Cyst Nematode Infection by Deep Sequencing. PloS ONE, 7(6), e39650. http://dx.doi.org/10.1371/journal.pone.0039650

Liao, Y. C., Li, H. P., Zhao, C. S., Yao, M. J., Zhang, J. B., \& Liu, J. L. (2006) Plantibodies: a novel strategy to create pathogen-resistant Plants. Biotechnology and Genetic Engineering Reviews, 23, 253-271. http://dx.doi.org/10.1080/02648725.2006.10648087

Luna, E., Bruce, T. J. A., Roberts, M. R., Flors, V., \& Ton, J. (2012). Next-Generation Systemic Acquired Resistance. Plant Physiol., 158, 844-853. http://dx.doi.org/10.1104/pp.111.187468

Maniatis, T., Fritsch, E. F., \& Sambrook, J. (1982). Molecular cloning: A laboratory manual (p. 545). New York: Cold Spring Harbor Lab.

Marcus, A., Efron, D., \& Week, D. P. (1974). The wheat embryo cell free system. Method Enzymol., 30(2), 749-754. http://dx.doi.org/10.1016/0076-6879(74)30073-0

Mirouze, M., \& Paszkowski, J. (2011). Epigenetic contribution to stress adaptation in plants. Curr. Opin. in 
Plant Biol., 14, 1-8. http://dx.doi.org/10.1016/j.pbi.2011.03.004

Mitkowski, N. A., \& Abawi, G. S. (2003). Root-knot nematodes. The Plant Health Instructor.

Moghaddam, M. R. B., \& Van den Ende, W. (2012). Sugars and plant innate immunity. J. Experim. Bot., 1-10.

Mourelatos, Z., Dostie, J., \& Paushkin, S. (2001). miRNPs: a novel class of ribonucleoproteins containing numerous microRNAs. Genes Dev., 16, 720-728. http://dx.doi.org/10.1101/gad.974702

Oka, Y. (2010). Mechanisms of nematode suppression by organic soil amendments. Appl. Soil. Ecol., 44, $101-115$. http://dx.doi.org/10.1016/j.apsoil.2009.11.003

Olaiya, C. O., Gbadegesin, M. A., \& Nwauzoma, A. B. (2013). Bioregulators as tools for plant growth, development, defence and improvement. African Journal of Biotechnology, 12(32), 4987-4999.

Padmanabhan., Ch., Zhang, X., \& Jin, H. (2009). Host small RNAs are big contributors to plant innate immunity. Curr. Opin. in Plant Biol., 12, 465-472. http://dx.doi.org/10.1016/j.pbi.2009.06.005

Park.,W., Song, L. J., Messing, R. J., \& Chen, X. (2002). CARPEL FACTORY, a dicer homolog, and HEN1, a novel protein, act in microRNA metabolism in Arabidopsis thaliana induced silencing complex (RISC), which targets homologous RNAs for degradation. Curr. Biol., 12, 484-1495. http://dx.doi.org/10.1016/S0960-9822(02)01017-5

Patel, N., Hamamaouch, N., Li, C., Hewezi, T., \& Hussey, R. S. (2010). A nematode effector protein similar to annexins in host plants. J. Exp. Bot., 61, 235-248. http://dx.doi.org/10.1093/jxb/erp293

Rasmann, S., De Vos, M., Casteel, C. L., Tian, D., Halitschke, R., Sun, J. Y., ... Jander, G. (2012). Herbivory in the Previous Generation Primes Plants for Enhanced Insect Resistance. Plant Physiol., 158, 854-863. http://dx.doi.org/10.1104/pp.111.187831

Sigareva, D. D. (1986). Methodical guidelines on revealing and the account of parasitic nematodes of field crops (p. 41). Kiev: Urojay.

Spoel, S. H., \& Dong, X. (2012). How do plants achieve immunity? Defence without specialized immune cells. Nature Reviews, Immunology, 12, 89-100. http://dx.doi.org/10.1038/nri3141

Sweere, D., Ponomarenko, S. P., Anishin, L. A., Babayants, O. V., \& Hrytsayenko, Z. M. (2011). Research of PGR efficiency in the farm Kyiv-Atlantic-Ukraine and the center of scientific providing of agroindustrial production of the Cherkasy region, Uman State Agrarian University and Odessa Selection and Genetic Institute. In S. P. Ponomarenko \& H. O. Iutynska (Eds.), New plant growth regulators: basic research and technologies of application (pp. 69-93). Kyiv: Nichlava.

Tang, G., Reinhart, B. J., Bartel, D. P., \& Zamore, P. D. (2003). A biochemical framework for RNA silencing in plants. Genes \& Development, 17, 49-63. http://dx.doi.org/10.1101/gad.1048103

Titus, D. E. (1991). Promega protocols and applications guide (2nd ed., p. 422). USA: Promega Corporation.

Tsygankova, V. A. Andrusevich, Ya. V., Beljavskaja, L. A., Kozyritskaja, V. E., Iutinskaja, H. A., Galkin, A. P., ... Boltovskaya, E. V. (2012). Growth stimulating, fungicidal and nematicidal properties of new microbial substances and their impact on si/miRNA synthesis in plant cells. Mikrobiol. J., 74(6), 3-12.

Tsygankova, V. A., Andrusevich, Ya. V., \& Blume, Ya. B. (2011). Isolation of small regulatory si/miRNA with antinematode activity from plant cells. Dopovidi Akademii nauk Ukrainy (Rep. Nat. Acad. Sci. Ukr.), 9, 159-164.

Tsygankova, V. A., Andrusevich, Ya. V., Babayants, O. V., Ponomarenko, S. P., Medkov, A. I., \& Galkin, A. P. (2013). Stimulation of plant immune protection against pathogenic fungi, pests and nematodes with growth regulators. Physiol. and biochem. cultivated plants, 45(2), 138-147.

Tsygankova, V. A., Andrusevich, Ya. V., Ponomarenko, S. P., Galkin, A. P., \& Blume, Ya. B. (2012). Isolation and Amplification of cDNA from the Conserved Region of the Nematode Heterodera schachtii $8 H 07$ Gene with a Close Similarity to Its Homolog in Rape Plants. Cytology and Genetics, 46(6), $335-341$. http://dx.doi.org/10.3103/S0095452712060114

Tsygankova, V. A., Galkin, A. P., Galkina, L. A., Musatenko, L. I., Ponomarenko, S. P., \&Iutynska, H. O. (2011). Gene expression under regulators' stimulation of plant growth and development. In S. P. Ponomarenko, \& H. O. Iutynska (Eds.), New plant growth regulators: basic research and technologies of application (pp. 94-152). Kyiv: Nichlava.

Tsygankova, V. A., Musatenko, L. I., Ponomarenko, S. P., Galkina, L. A., Andrusevich, Ya. V. \& Galkin, A. P. 
(2010). Change of functionally active cytoplasmical mRNA populations in plant cells under growth regulators effect and biological perspectives of cell-free systems of protein synthesis. Biotechnol., 3(2), 19-32.

Tsygankova, V. A., Stefanovska, T. R., Andrusevich, Ya. V., Ponomarenko, S. P., Galkin, A. P., Blume, \& Ya. B. (2012). Induction of biosynthesis of si/miRNA with antipathogenic and antiparasitic properties in plant cells by growth regulators. Biotechnol., 3, 62-74.

Tsygankova, V. A., Stefanovska, T. R., Galkin, A. P., Ponomarenko, S. P., \& Blume, Ya. B. (2012). Inducing effect of PGRs on small regulatory si/miRNA in resistance to sugar beet cyst nematode. Comm. Appl. Biol. Sci., Ghent University (Belgium), 77(4), 779-788.

Tsygankova, V. A., Yemets, A. I., Iutinska, H. O., Beljavska, L. O., Galkin, A. P., \& Blume, Ya. B. (2013). Increasing the Resistance of Rape Plants to the Parasitic Nematode Heterodera schachtii Using RNAi Technology. Cytology and Genetics, 47(4), 222-230.

Tsygankova, V. A. (2012). Genetic mechanisms of wheat and chickpea (Cicer arietinum L.) inheritance of resistance to pathogenic micromycete of Fusarium L. genus. Dopovidi Akademii nauk Ukrainy (Rep. Nat. Acad. Sci. Ukr.), 11, 185-190.

Tsygankova, V. A., Ponomarenko, S. P., \&Blume, Ya. B. (2012). The molecular genetic mechanisms of plant growth regulators' action with bioprotective properties. Bull. Vavilov Soc. Genet. Breed.Ukr., 10(1), 86-94. http://dx.doi.org/10.3103/S0095452713040105

Tuschl, T., Zamore, P. D., Lehmann, R., Bartel, D. P., \& Sharp, P. A. (1999). Targeted mRNA degradation by double-stranded RNA in vitro. Genes and development, 13, 3191-3197. http://dx.doi.org/10.1101/gad.13.24.3191

Vaucheret, H. (2006). Post-transcriptional small RNA pathways in plants: mechanisms and regulations. Genes \& Development, 20, 759-771. http://dx.doi.org/10.1101/gad.1410506

Vaucheret, H., Béclin, C., \& Fagard, M. (2001). Post-transcriptional gene silencing in plants. J. Cell Sci., 114, 3083-3091.

Vavrina, C. S., Roberts, P. D., Kokalis-Burelle N., \& Ontermaa E. O. (2004). Greenhouse Screening of Commercial Products Marketed as Systemic Resistance and Plant Growth Promotion Inducers. Hort Science, 39(2), 433-437.

Verhage, A., van Wees, S. C. M., \& Pieterse, C. M. J. (2010). Plant Immunity: It's the Hormones Talking, But What Do They Say? Plant Physiology, 154, 536-540. http://dx.doi.org/10.1104/pp.110.161570

Winter, S. M. J., Rajcan, I., \& Shelp, B. J. (2006). Soybean cyst nematode: Challenges and opportunities. Canadian Journal of Plant Science, 86(1), 25-32. http://dx.doi.org/10.4141/P05-072

Zhang, B., Wang, Q., \& Pan, X. (2007). MicroRNAs and their regulatory roles in animals and plant. J. Cell. Physiol., 210, 279-289. http://dx.doi.org/10.1002/jcp.20869

Zhang, W., Gao, S., Zhou, X., Chellappan., P, Chen, Z., Zhou, X., \& Zhang, X. (2011). Bacteria-responsive microRNAs regulate plant innate immunity by modulating plant hormone networks. Plant Mol. Biol., 75, 93-105. http://dx.doi.org/10.1007/s11103-010-9710-8

\section{Copyrights}

Copyright for this article is retained by the author(s), with first publication rights granted to the journal.

This is an open-access article distributed under the terms and conditions of the Creative Commons Attribution license (http://creativecommons.org/licenses/by/3.0/). 